\title{
Comparison of Triglyceride/Glucose Index with the FINDRISC Diabetes Risk Questionnaire in Determining Diabetes Risk in Individuals Attending Periodic Health Examinations
}

\author{
Periyodik Sağlık Muayenesi için Başvuran Bireylerde Diyabet Riskini Belirlemede \\ Trigliserit/Glikoz Indeksinin "FINDRISK" Diyabet Risk Anketi ile Karşılaştırılması
}

\author{
Nur Demirbas $\oplus^{\oplus}$, Ruhuşen Kutlu $\odot$ \\ Necmettin Erbakan University Meram Medical Faculty Department of Family Medicine, Konya, Turkey
}

Received: 27 December 2019 / Accepted: 14 March 2020 / Publication date: 26 June 2020

Cite as: Demirbas N, Kutlu R. Comparison of triglyceride/glucose index with the FINDRISC diabetes risk questionnaire in determining diabetes risk in individuals attending periodic health examinations. Med J Bakirkoy 2020;16(2):165-73.

\begin{abstract}
Objective: In this study, we aimed to compare the FINDRISC questionnaire and the triglyceride/glucose index, used to determine the risk of diabetes in healthy individuals, and to investigate their relationships with obesity.

Method: This study was planned as a retrospective review of the files of healthy individuals who had applied to a family medicine polyclinic for a periodic health examination. Sociodemographic characteristics, anthropometric measurements, routine laboratory results from the same period, and the FINDRISC diabetes risk score found in the participants' files were recorded in a separate file. The triglyceride/glucose $(T y G)$ index was calculated using the appropriate formula. After the files meeting the exclusion criteria were removed, the study was completed with 879 people.

Results: Of the participants, $66.7 \%$ ( $n=586)$ were male and the mean age was $37.20 \pm 11.8$ years. The mean diabetes risk score calculated by FINDRISC for women was $10.92 \pm 4.9$ points and the mean TyG index score was $8.56 \pm 0.5$ points, while the mean diabetes risk score of men was $8.75 \pm 4.7$ points and the mean TyG index score was $8.77 \pm 0.5$. There was a statistically significant association between gender and both mean diabetes risk score and TyG index $(p<0.001)$. Of the participants, $17.1 \%$ were found to be at high risk of developing diabetes within 10 years by the FINDRISC survey. There was a moderately significant positive correlation between the diabetes risk score and TyG index and body mass index.

Conclusion: The FINDRISC questionnaire and TyG index are easy, practical, and cost-effective methods that can be used in primary health care centers in order to determine the risk of developing diabetes in the early period and inform individuals about this issue.
\end{abstract}

Keywords: healthy individual, diabetes risk, FINDRISC questionnaire, triglyceride/glucose index

öz

Amaç: Bu çalışmada sağıılı bireylerde diyabet riskini belirlemek için kullanılan FINDRISK anketi ile trigliserit/glikoz indeksini karşılaştırmayı ve obezite ile ilişkilerini araştırmayı amaçladık.

Yöntem: Bu çalışma aile hekimliği polikliniğine periyodik sağlık muayenesi için başvurmuş sağlıklı bireylerin dosyalarının retrospektif taraması olarak planlandı. Katılımcıların dosyalarında bulunan sosyodemografik özellikleri, antropometrik ölçümleri, aynı dönemde yapılmıs rutin laboratuvar sonuçları ile FINDRISK diyabet risk puanı ayrı bir dosyaya kaydedildi. Uygun formül kullanılarak trigliserit/glikoz (TyG) indeksi hesaplandı. Dışlama kriterlerine uyan dosyalar çıkarıldıktan sonra araştırma 879 kişi ile tamamlandı.

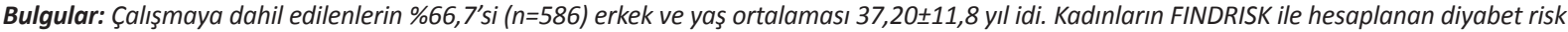
puanı ortalaması 10,92 $\pm 4,9$ puan, TyG indeksi ortalaması $8,56 \pm 0,5$ ve erkeklerin diyabet risk puanı ortalaması $8,75 \pm 4,7$ puan, TyG indeksi orta-

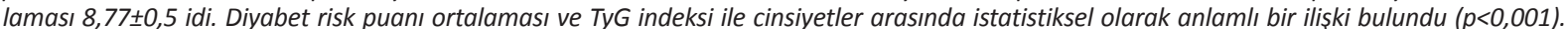
Katılımcıların \%17, 1'inde FINDRISK anketi ile 10 yıl içinde diyabet gelişme riski yüksek olarak bulundu. Diyabet risk puanı ve TyG indeksi ile beden kitle indeksi arasında pozitif yönde orta derecede anlamlı bir korelasyon vardı.

Sonuç: FINDRISK anketi ve trigliserit/glikoz indeksi sağlıklı görünen bireylerde diyabet gelişim riskini erken dönemde tespit etmek ve bireyleri bu konuda bilgilendirebilmek için birinci basamakta kullanılabilecek kolay, pratik ve uygun maliyetli yöntemlerdir.

Anahtar kelimeler: sağlıklı birey, diyabet riski, FINDRISK anketi, trigliserit/glikoz indeksi 


\section{INTRODUCTION}

Diabetes mellitus (DM) is a chronic metabolic disease and a serious public health problem that requires continuous medical care because the body cannot make sufficient use of carbohydrates, fats, and proteins due to insulin deficiency or impairments in the effects of insulin. There has been a worldwide increase in the prevalence of DM due to many factors such as increasing obesity and sedentary lifestyle. This creates an important burden for the health economy due to both illness and complications ${ }^{(1)}$. The prevalence of DM is $8.8 \%$ worldwide and $14.7 \%$ in Turkey ${ }^{(1,2)}$.

Type $2 \mathrm{DM}$ is a disease with an asymptomatic period and accounts for about $90-95 \%$ of all cases of DM ${ }^{(2)}$. Community-based studies show that nearly half of DM patients in Turkey are not yet aware of their disease ${ }^{(3)}$. It is possible to detect DM during this asymptomatic period, to detect and regulate risk factors, and to stop or delay the onset of the disease (4). Simple, effective, reliable, and widely applicable tools are being developed to ensure diabetes awareness. In recent years, researchers have proposed several risk factors, predictive models, and inflammatory biomarkers for identifying people at high risk for type 2 diabetes in the future ${ }^{(5-7)}$. However, data on the role of inflammatory biomarkers such as highsensitivity C-reactive protein, tumor necrosis factoralpha, or interleukin- 6 are limited. Furthermore, these new markers are impractical and expensive for use in primary health care ${ }^{(8)}$. Insulin resistance (IR), the main indicator used in the diagnosis of DM, is defined as a decrease of cells' glucose uptake even at certain insulin concentrations. There are several methods for the diagnosis of IR. In clinical practice, the hyperinsulinemic-euglycemic clamp method is considered the gold standard, but it is expensive and difficult to apply ${ }^{(9)}$. The homeostasis model assessment of insulin resistance (HOMA-IR) is one of the most widely used methods for assessing IR in healthy people ${ }^{(10)}$. However, it is necessary to measure serum insulin levels to calculate HOMA-IR, and this measurement is not a part of routine evaluation in health care services.

The relationship between fasting blood glucose (FBS) and triglyceride (TG) levels with the development of type 2 diabetes has been reported in the literature ${ }^{(11,12)}$. The triglyceride/glucose (TyG) index is a new index proposed as an indicator of IR ${ }^{(13-15)}$. A number of recent studies have shown a significant correlation between the clamp method and HOMA-IR and the TyG index ${ }^{(16,17)}$. Although many studies have been conducted on the TyG index as a predictor of type 2 diabetes in many countries of the world, the number of studies on this subject is limited in Turkey.

Today, survey studies are also conducted to evaluate the risk of diabetes in adults. One of these tools is the Finnish Diabetes Risk Score (FINDRISC). The FINDRISC questionnaire identifies the risk of the development of diabetes in adults over the next decade and allows for early diagnosis of high-risk individuals.

In this study, we aimed to compare the TyG index and FINDRISC questionnaire, used as predictors of diabetes, to determine the risk of diabetes in healthy individuals and their relationship with obesity.

\section{MATERIALS AND METHODS}

\section{Place, type, and universe of the study}

This study was planned as a retrospective review of the files of healthy individuals over 18 years old who attended a family medicine outpatient clinic between January 1, 2014 and December 31, 2016 for periodic health examinations. In this period, the files of individuals who applied to our outpatient clinic were examined and sociodemographic characteristics such as age, gender, marital status, educational status, and smoking status; anthropometric measurements such as height, weight, and waist circumference; systolic and diastolic blood pressures; and fasting blood glucose and lipid parameter results were recorded in a separate program for analysis. The participants' health habits and scores from the FINDRISC diabetes risk questionnaire were recorded.

The following individuals were excluded from the study: those with incomplete information; those with congenital or subsequent body abnormalities; patients with cancer; patients with diseases that would affect blood sugar and lipid parameters and those using drugs for this; patients with bone, endocrine, and metabolic diseases; pregnant women and those in puerperium; those receiving medical or 
surgical obesity treatment; diabetes patients; those receiving treatment for hypertension; and those under 18 years of age. Considering the exclusion criteria, the study was completed with 879 individuals.

Ethics committee approval: Before starting the study, approval of the Necmettin Erbakan University Meram Medical Faculty's Non-Interventional Clinical Research Ethics Committee (2019/2172) was obtained.

Data collection: Weight, height, and waist circumference were recorded as anthropometric measurements from the study participants' files and body mass index (BMI) was calculated as BMI=weight $(\mathrm{kg}) /$ height $\left(\mathrm{m}^{2}\right)$. BMIs of 18.50-24.99 were evaluated as normal weight, 25.0-29.99 as overweight, and $\geq 30.0$ as obese. BMIs of $<18.5$ were not included in the study because of the small number of people. Fasting blood glucose (FBS), total cholesterol (T-Chol), triglyceride (TG), high-density lipoprotein (HDL-c), and low-density lipoprotein (LDL-C) values were recorded from patients' files. The TyG index was calculated according to the following formula:

Triglyceride/Glucose (TyG) Index: In[triglyceride (mg/ $\mathrm{dL}) \times$ fasting glucose $(\mathrm{mg} / \mathrm{dL}) / 2]^{(18)}$.

Diabetes Risk Questionnaire (FINDRISC): The FINDRISC questionnaire ${ }^{(19)}$, developed by the Finnish Diabetes Association within the scope of the Finnish Type 2 Diabetes Prevention Programme, is also widely used in our country and is recommended by the Turkish Society of Endocrinology and Metabolism (TEMD). This questionnaire determines the risk of developing diabetes in the next decade (2). The FINDRISC questionnaire consists of 8 questions: age, $\mathrm{BMI}$, waist circumference, physical activity, fruit and vegetable consumption, history of antihypertensive medication, high blood sugar, and family history of diabetes. The scores corresponding to the answers are summed and the total diabetes risk score, ranging from 0 to 26 , is calculated. If the total score is $<7$, the risk is low (1\%), while $7-11$ points signify mild risk (4\%), 12-14 points moderate risk (16\%), $15-19$ points high risk (33\%), and $\geq 20$ points very high risk (50\%).

Statistical Analysis: SPSS 20.0 for Windows was used for statistical analysis. Descriptive statistics of conti- nuous variables are given as means and standard deviations, and descriptive statistics of categorical data are given in terms of frequency and percentage. Compliance with normal distribution was evaluated by the Kolmogorov-Smirnov test. Accordingly, oneway ANOVA was used to compare quantitative data showing normal distribution. The post hoc Tukey test was performed when there was a significant difference between groups. The chi-square test was used to compare categorical data. Pearson correlation analysis was used for correlations between parameters. Correlation coefficients $(r)$ of $0.00-0.24$ were evaluated as weak relationships, $0.25-0.49$ as moderate, $0.50-0.74$ as strong, and $0.75-1.00$ as very strong. Linear regression analysis was performed between two variables and the regression coefficient was calculated. The results were evaluated with $95 \%$ confidence intervals and $p<0.05$ significance level.

\section{RESULTS}

A total of 879 participants who applied to the family medicine outpatient clinic for periodic health examinations were included in the study; $66.7 \%(n=586)$ were male, $33.3 \%(n=293)$ were female, and the mean age was $37.20 \pm 11.8$ years (range: $18-76$ ). The sociodemographic characteristics of the participants are shown in Table 1.

The mean BMI of the women participating in the study was $31.48 \pm 6.6 \mathrm{~kg} / \mathrm{m}^{2}$ and the mean waist circumference was $95.24 \pm 15.1 \mathrm{~cm}$, while the mean BMI of the men was $28.62 \pm 5.2 \mathrm{~kg} / \mathrm{m}^{2}$ and the mean waist circumference was $99.33 \pm 14.3 \mathrm{~cm}$. A statistically significant relationship was found between both waist circumference and BMI and gender $(p<0.001)$. The mean BMI of women was greater than that of men, while the mean waist circumference of men was greater than that of women. The mean diabetes risk score calculated by FINDRISC for women was $10.92 \pm 4.9$ points and the mean TyG index was $8.56 \pm 0.5$, while for men, the mean diabetes risk score was $8.75 \pm 4.7$ points and the mean TyG index was $8.77 \pm 0.5$. There was a statistically significant relationship between the mean diabetes score and TyG index $(p<0.001)$ (Table 2).

According to the FINDRISC questionnaire, participants were divided into 3 groups in terms of the risk 
Table 1. Sociodemographic characteristics of the participants.

\begin{tabular}{|c|c|c|}
\hline \multirow[b]{2}{*}{ Age (years) } & \multicolumn{2}{|c|}{ Mean $\pm S D$} \\
\hline & $\begin{array}{c}37.20 \pm 11.8 \\
\mathbf{n}\end{array}$ & $\begin{array}{c}(18-76) \\
\%\end{array}$ \\
\hline \multicolumn{3}{|l|}{ Gender } \\
\hline Male & 586 & 66.7 \\
\hline Female & 293 & 33.3 \\
\hline \multicolumn{3}{|l|}{ Marital status } \\
\hline Married & 691 & 78.6 \\
\hline Single & 188 & 21.4 \\
\hline \multicolumn{3}{|l|}{ Occupation } \\
\hline Employed & 374 & 42.5 \\
\hline Unemployed/retired & 505 & 57.5 \\
\hline \multicolumn{3}{|l|}{ Education status } \\
\hline Primary school or less & 337 & 38.3 \\
\hline Secondary school & 234 & 26.6 \\
\hline Higher education & 308 & 35.1 \\
\hline \multicolumn{3}{|l|}{ Smoking status } \\
\hline Smoker & 251 & 28.6 \\
\hline Nonsmoker & 628 & 71.4 \\
\hline
\end{tabular}

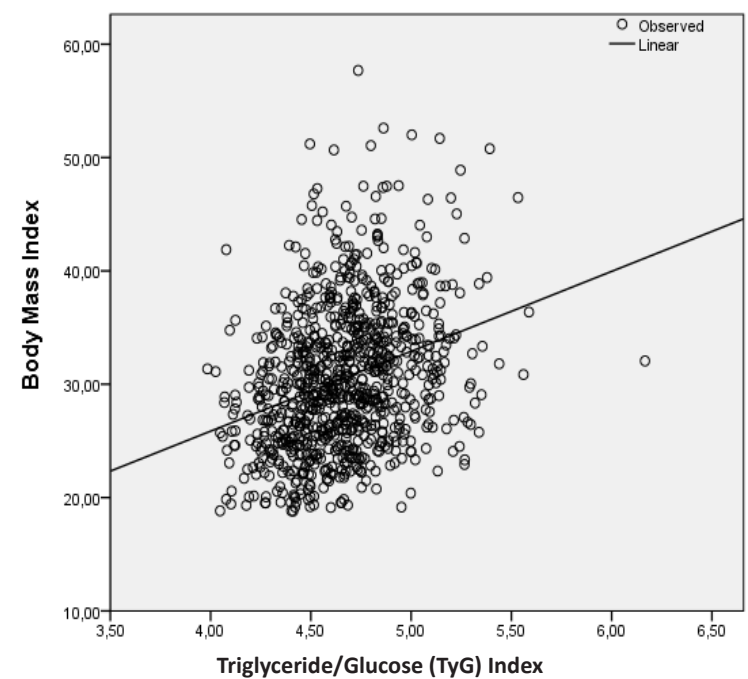

of developing diabetes within 10 years. Those who scored 11 points or fewer from the questionnaire ( $n=552,62.8 \%$ ) were considered to be of low/mild risk, those who scored $12-14(n=177,20.1 \%)$ were of moderate risk, and those who scored 15 or above ( $n=150,17.1 \%$ ) were of high risk. The mean BMI, waist circumference, FBS, and TyG index of the participants in the group with a high risk of diabetes were higher than those with mild and moderate risk and the difference was statistically significant $(p<0.001)$ (Table 3 ).

The TyG index was divided into 4 groups according to percentile values. Waist circumference, BMI, and FINDRISC diabetes risk scores of those with TyG index values of $\geq 8.97$ were also higher than those of the other groups and this difference was statistically significant $(p<0.001)$ (Table 4).

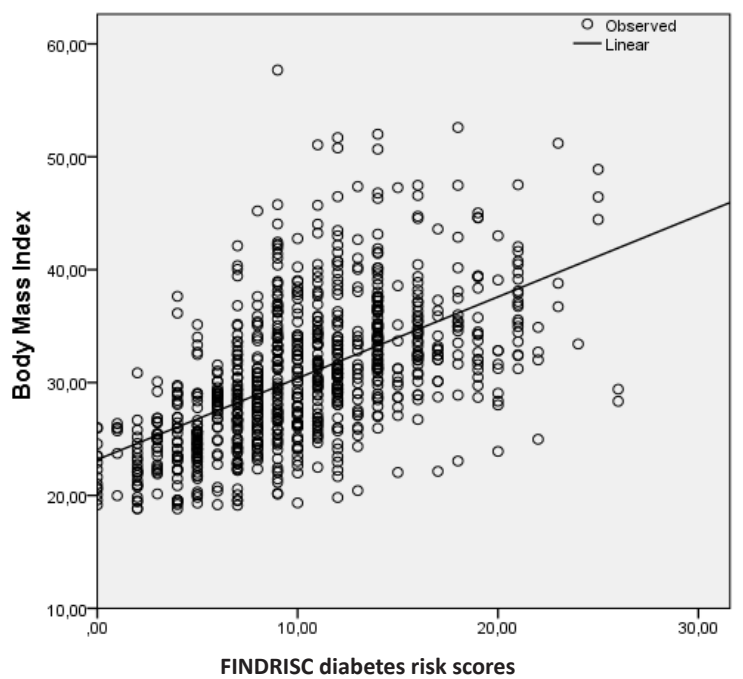

Figure 1. Linear regression graphs for TyG index and diabetes risk score and BMI.

Table 2. Comparison of some parameters with the genders of the participants.

\begin{tabular}{|c|c|c|c|c|}
\hline & $\begin{array}{l}\text { Female } \\
\text { Mean士SD }\end{array}$ & $\begin{array}{c}\text { Male } \\
\text { Mean } \pm S D\end{array}$ & $\mathbf{t}$ & $\mathbf{p}$ \\
\hline BMI $\left(\mathrm{kg} / \mathrm{m}^{2}\right)$ & $31.48 \pm 6.6$ & $28.62 \pm 5.2$ & 6.946 & $<0.001$ \\
\hline Waist circumference $(\mathrm{cm})$ & $95.24 \pm 15.1$ & $99.33 \pm 14.3$ & -3.861 & $<0.001$ \\
\hline Systolic BP (mmHg) & $126.95 \pm 13.8$ & $129.88 \pm 12.7$ & -3.117 & 0.002 \\
\hline Diastolic BP (mmHg) & $77.44 \pm 10.1$ & $77.44 \pm 9.44$ & 0.012 & 0.990 \\
\hline Fasting blood glucose $(\mathrm{mg} / \mathrm{dL})$ & $96.53 \pm 19.0$ & $96.33 \pm 15.9$ & 0.155 & 0.877 \\
\hline $\mathrm{T}-\mathrm{Chol}(\mathrm{mg} / \mathrm{dL})$ & $190.16 \pm 39.4$ & $190.63 \pm 44.5$ & -0.153 & 0.878 \\
\hline LDL-c (mg/dL) & $117.19 \pm 32.2$ & $122.60 \pm 38.5$ & -2.077 & 0.038 \\
\hline HDL-c (mg/dL) & $48.07 \pm 10.1$ & $39.73 \pm 8.6$ & 12.680 & $<0.001$ \\
\hline Triglyceride (mg/dL) & $124.13 \pm 73.1$ & $153.74 \pm 81.9$ & -5.231 & $<0.001$ \\
\hline Diabetes risk score & $10.92 \pm 4.9$ & $8.75 \pm 4.7$ & 6.184 & $<0.001$ \\
\hline TyG index & $8.56 \pm 0.5$ & $8.77 \pm 0.5$ & -5.516 & $<0.001$ \\
\hline
\end{tabular}


Table 3. Comparison of some parameters with participants' diabetes risk status.

\begin{tabular}{|c|c|c|c|c|c|}
\hline & $\begin{array}{c}\text { Low }^{\text {(mild risk }} \text { a }^{(n=552)} \\
\text { Mean } \pm S D\end{array}$ & $\begin{array}{c}\text { Moderate risk } \\
(n=177) \\
\text { Mean } \pm \text { SD }\end{array}$ & $\begin{array}{l}\text { High-very high risk } \\
(n=150) \\
\text { Mean } \pm \text { SD }\end{array}$ & $\mathbf{F}$ & $\mathbf{p}$ \\
\hline BMI $\left(\mathrm{kg} / \mathrm{m}^{2}\right)$ & $28.34 \pm 5.6$ & $33.52 \pm 5.8$ & $35.01 \pm 5.6$ & 111.223 & $\begin{array}{l}<0.001^{\mathrm{ab}} \\
<0.001^{\mathrm{ac}}\end{array}$ \\
\hline Waist circumference $(\mathrm{cm})$ & $92.52 \pm 13.7$ & $102.23 \pm 14.0$ & $104.97 \pm 14.4$ & 65.079 & $\begin{array}{l}<0.001^{\mathrm{at}} \\
<0.001^{\mathrm{ac}}\end{array}$ \\
\hline Systolic BP (mmHg) & $125.53 \pm 12.2$ & $129.60 \pm 13.1$ & $134.78 \pm 16.1$ & 31.098 & $\begin{array}{c}0.001^{\mathrm{ab}} \\
<0.001^{\mathrm{ac}} \\
0.005^{\mathrm{bc}}\end{array}$ \\
\hline Diastolic BP (mmHg) & $76.04 \pm 9.3$ & $78.48 \pm 9.8$ & $81.36 \pm 10.8$ & 18.841 & $\begin{array}{c}0.012^{\mathrm{ab}} \\
<0.001^{\mathrm{a}} \mathrm{c} \\
0.039^{\mathrm{bc}}\end{array}$ \\
\hline Fasting blood glucose (mg/dL) & $92.95 \pm 12.5$ & $97.29 \pm 14.2$ & $108.42 \pm 29.9$ & 48.340 & $\begin{array}{l}0.001^{\mathrm{ab}} \\
<0.001^{\mathrm{ab}} \\
<0.001^{\mathrm{bc}}\end{array}$ \\
\hline T-Chol (mg/dL) & $186.03 \pm 40.2$ & $195.45 \pm 41.6$ & $200.03 \pm 42.1$ & 8.673 & $\begin{array}{l}0.026^{\text {ab }} \\
0.001^{\text {ac }} \\
<0.001^{\text {bc }}\end{array}$ \\
\hline LDL-c (mg/dL) & $115.63 \pm 34.1$ & $123.45 \pm 35.2$ & $126.10 \pm 33.2$ & 7.397 & $\begin{array}{l}0.030^{\mathrm{ab}} \\
0.002^{\mathrm{ac}}\end{array}$ \\
\hline HDL-c (mg/dL) & $45.48 \pm 10.5$ & $44.68 \pm 11.0$ & $45.28 \pm 9.2$ & 0.397 & 0.673 \\
\hline Triglyceride (mg/dL) & $127.56 \pm 78.7$ & $141.47 \pm 79.3$ & $148.87 \pm 67.0$ & 5.562 & $0.003^{\mathrm{ac}}$ \\
\hline TyG index & $8.54 \pm 0.5$ & $8.70 \pm 0.5$ & $8.87 \pm 0.51$ & 24.685 & $\begin{array}{c}0.001^{\mathrm{ab}} \\
<0.001^{\mathrm{ac}} \\
0.011^{\mathrm{bc}}\end{array}$ \\
\hline
\end{tabular}

When correlations of variables with the diabetes risk scores of the participants were examined, there was a moderate positive correlation with age, waist circumference, and FBS and a strong positive correlation with BMI $(r=0.348, r=0.481, r=0.341$, $\mathrm{p}<0.001)$. Also, there was a moderate positive correlation between age, BMI, waist circumference, and FBS and the TyG index $(r=0.332, r=0.305$, $r=0.382, r=0.468, p<0.001)$. The correlations between diabetes risk score and TyG index and other parameters are shown in Table 5.

When linear regression analysis was performed, $32.0 \%$ of the increase in diabetes risk score and $9.3 \%$ of the increase in TyG index was attributed to increase in BMI (Figure 1).

\section{DISCUSSION}

The results of our study are important because this is one of the few studies conducted with the FINDRISC questionnaire and the TyG index, the predictor of insulin resistance, used to predict early diabetes development in our country.

According to FINDRISC, $17.1 \%$ of the participants were at high risk of developing DM within 10 years. In a study conducted to determine the risk of diabetes in hospital employees, $7.8 \%$ of the employees were found to be high-risk with the FINDRISC survey (20). In another study conducted in healthy adults, the risk of diabetes was found to be high in $19.3 \%$ of the participants as a result of FINDRISC ${ }^{(21)}$. In a study conducted in our region, the frequency of those with high risk of diabetes was found to be $15.5 \%$, similar to our present results ${ }^{(22)}$. In the study of Iğci et al., applying the ADA diabetes risk questionnaire to 3138 people, the percentage of those with a high risk of diabetes was found to be $32 \%{ }^{(23)}$. This difference may be due to the different number of partici- 
Table 4. Comparison of some parameters with TyG index of participants.

\begin{tabular}{|c|c|c|c|c|c|}
\hline & $\begin{array}{c}\text { TyG } \leq 8.24^{\mathrm{a}} \\
\text { Mean } \pm S D\end{array}$ & $\begin{array}{c}\text { TyG: } 8.24-8.61^{b} \\
\text { Mean } \pm S D\end{array}$ & $\begin{array}{c}\text { TyG:8.61-8.97c } \\
\text { Mean } \pm S D\end{array}$ & $\begin{array}{c}\text { TyG } \geq 8.97^{d} \\
\text { Mean } \pm S D\end{array}$ & p \\
\hline Waist circumference $(\mathrm{cm})$ & $88.63 \pm 12.2$ & $94.53 \pm 15.0$ & $99.0 \pm 14.0$ & $109.99 \pm 13.7$ & $\begin{array}{c}<0.001^{\mathrm{ab}} \\
<0.001^{\mathrm{ac}} \\
0.004^{\mathrm{bc}}\end{array}$ \\
\hline BMI $\left(\mathrm{kg} / \mathrm{m}^{2}\right)$ & $27.57 \pm 5.2$ & $30.19 \pm 6.2$ & $31.31 \pm 6.3$ & $32.93 \pm 6.4$ & $\begin{array}{c}<0.001^{a b} \\
<0.001^{a d} \\
0.026^{c d}\end{array}$ \\
\hline Systolic BP (mmHg) & $122.68 \pm 12.2$ & $125.54 \pm 11.9$ & $130.14 \pm 13.2$ & $133.17 \pm 14.3$ & $\begin{array}{l}<0.001^{\text {ad }} \\
<0.001^{a c} \\
<0.001^{b c}\end{array}$ \\
\hline Diastolic BP (mmHg) & $74.33 \pm 10.0$ & $76.53 \pm 9.7$ & $79.41 \pm 9.2$ & $79.43 \pm 9.8$ & $\begin{array}{l}<0.001^{\text {ad }} \\
<0.001^{a c} \\
<0.001^{\text {bc }}\end{array}$ \\
\hline Fasting blood glucose (mg/dL) & $89.07 \pm 7.3$ & $93.53 \pm 10.3$ & $95.67 \pm 10.0$ & $107.28 \pm 29.0$ & $\begin{array}{c}<0.001^{a c} \\
<0.001^{b c} \\
0.028^{a b}\end{array}$ \\
\hline T-Chol (mg/dL) & $168.96 \pm 35.1$ & $181.89 \pm 35.0$ & $196.87 \pm 36.8$ & $212.83 \pm 43.6$ & $\begin{array}{l}<0.001^{\text {ac }} \\
0.021^{\text {bc }}\end{array}$ \\
\hline LDL-c (mg/dL) & $103.73 \pm 30.1$ & $116.92 \pm 31.1$ & $126.49 \pm 33.5$ & $128.47 \pm 36.9$ & $\begin{array}{l}0.014^{\mathrm{bc}} \\
<0.001^{\text {ad }}\end{array}$ \\
\hline HDL-c (mg/dL) & $50.95 \pm 11.2$ & $46.20 \pm 9.6$ & $43.79 \pm 9.7$ & $40.37 \pm 8.0$ & $\begin{array}{l}<0.001^{\text {ac }} \\
<0.001^{\text {bc }}\end{array}$ \\
\hline Triglyceride (mg/dL) & $66.32 \pm 13.9$ & $98.59 \pm 13.7$ & $137.18 \pm 18.4$ & $231.07 \pm 87.7$ & $\begin{array}{l}<0.001^{\text {ac }} \\
<0.001^{\text {bc }}\end{array}$ \\
\hline Diabetes risk score & $8.12 \pm 4.0$ & $9.73 \pm 4.5$ & $10.72 \pm 5.1$ & $12.16 \pm 5.3$ & $\begin{array}{l}<0.001^{\text {ab }} \\
<0.001^{\text {ac }} \\
<0.001^{\text {bc }}\end{array}$ \\
\hline
\end{tabular}

pants and the questionnaire used for risk assessment. According to 2017 International Diabetes Federation (IDF) data, the incidence of diabetes in Turkey is reported to be $14.7 \%$ and it is estimated that this rate will increase gradually in the next 15 years $^{(1)}$. In the present study, a significant relationship was found between age and gender of the participants and their diabetes risk scores. The risk score was higher in older individuals and females, while it was higher in younger participants and males. Contrary to this study, no significant association between 10-year diabetes risk and gender was identified in some other studies of diabetes risk (20-22). Although the community-based TURDEP-2 study to determine the prevalence of DM in Turkey found DM to be more common in women, no significant relationship between gender and DM frequency was found ${ }^{(3)}$. In our study, the reason for the higher risk of diabetes in females than males may be that the women living in our region have higher BMIs and waist circumferences due to a lack of physical activity and nutritional patterns, and this may increase the risk of diabetes. Obesity and high waist circumference are the most important factors that increase the risk of diabetes, as shown in many studies (20-24).

The TyG index is calculated based on the individual's measured triglyceride and fasting blood sugar using the formula $\ln$ [triglyceride $(\mathrm{mg} / \mathrm{dL}) \times$ fasting glucose $(\mathrm{mg} / \mathrm{dL}) / 2$ ]. Many prospective studies in the literature in recent years have shown that the TyG index is associated with new-onset diabetes ${ }^{(25)}$, hypertension ${ }^{(26)}$, and cardiovascular events ${ }^{(27,28)}$. In a cohort study aimed to evaluate the role of the TyG index in predicting and mediating the development of cardiovascular disease (CVD), the TyG index of 6078 par- 
Table 5. Correlation between TyG index and diabetes risk score and some parameters.

\begin{tabular}{|c|c|c|c|c|}
\hline & \multicolumn{2}{|c|}{ Diabetes risk score } & \multicolumn{2}{|c|}{ TyG index } \\
\hline & $\mathbf{r}$ & $\mathbf{p}$ & $\mathbf{r}$ & $\mathbf{p}$ \\
\hline Age & $0.348 * *$ & $\mathrm{p}<0.001$ & $0.322 * *$ & $p<0,001$ \\
\hline BMI (kg/m2) & $0.566 * *$ & $\mathrm{p}<0.001$ & $0.305 * *$ & $p<0,001$ \\
\hline Waist circumference (cm) & $0.481 * *$ & $\mathrm{p}<0.001$ & $0.382 * *$ & $p<0,001$ \\
\hline Systolic BP (mmHg) & $0.286 * *$ & $\mathrm{p}<0.001$ & $0.280 * *$ & $p<0,001$ \\
\hline Diastolic BP (mmHg) & $0.261 * *$ & $\mathrm{p}<0.001$ & $0.192 * *$ & $p<0,001$ \\
\hline Fasting blood glucose (mg/dL) & $0.341 * *$ & $\mathrm{p}<0.001$ & $0.468 * *$ & $p<0,001$ \\
\hline T-Chol (mg/dL) & $0.176 * *$ & $\mathrm{p}<0.001$ & $0.443 * *$ & $p<0,001$ \\
\hline LDL-c (mg/dL) & $0.148 * *$ & $\mathrm{p}<0.001$ & $0.267 * *$ & $p<0,001$ \\
\hline HDL-c (mg/dL) & $-0.033 * *$ & $\mathrm{p}<0.001$ & $-0.366 * *$ & $p<0,001$ \\
\hline Triglyceride (mg/dL) & $0.152 * *$ & $\mathrm{p}<0.001$ & $0.904 * *$ & $p<0,001$ \\
\hline Diabetes risk score & \multicolumn{2}{|c|}{1} & $0.279 * *$ & $p<0.001$ \\
\hline TyG index & $0.279 * *$ & $\mathrm{p}<0.001$ & \multicolumn{2}{|c|}{1} \\
\hline
\end{tabular}

ticipants over 60 years of age was calculated and a significant relationship was shown between increasing TyG and CVD, which increased over time ${ }^{(29)}$. In this study, we found that systolic and diastolic blood pressures were higher in individuals with a high TyG index. A study in Chinese adults has been shown that a higher TyG index, regardless of obesity, synergistically increases the risk of prehypertension, and the TyG index has a higher predictability for HT compared to traditional indices ${ }^{(30)}$. In another study, the relationship between the Increasing TyG index and prehypertension and hypertension risk was determined (31).

In a study in which 617 adults without diabetes were followed for approximately 9 years, the TyG index was used to evaluate the risk of developing diabetes, and it was found that the frequency of diabetes development was higher in patients with high TyG index over time than in those with a low index. While there is no relationship between gender and diabetes development, it has been shown that the frequency of diabetes development increases with age

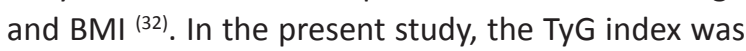
found to be significantly higher in women than in men. Although triglyceride levels were lower in female participants than in men, there was no difference between fasting blood glucose levels, and this may have caused the difference in the index.

In a comparative study that applied HOMA-IR and the TyG index to evaluate insulin resistance, the TyG index was found to be significantly higher in patients with high HOMA-IR values and the positive predictive value of the TyG index was calculated as $73.3 \%{ }^{(33)}$. In a previous study to predict the development of diabetes and cardio-metabolic changes, the area under the curve (AUC) in ROC analysis was 0.790 for FBS and 0.640 for the TyG index, while the AUC was 0.802 for the TyG index in another study ${ }^{(30,31)}$. In their study, Unger et al determined the TyG index cut-off point as 8.8 for patients with metabolic syndrome ${ }^{(14)}$. According to our study, the frequency of those with the TyG index above 8.8 was found to be $35.4 \%(n=311)$. According to the results of the FINDRISC questionnaire, the frequency of those with medium and high risk was $37.2 \%$ $(n=327)$. The two tests are compatible with each other. In a different study, the cut off value was used between 8.15-8.65 for different groups (34). In our study, we found that those with a TyG value of 8.97 and above are at high risk.

In a comparative study using $\mathrm{HbA} 1 \mathrm{C}$ and the TyG index as predictors of glycemic control in type $2 \mathrm{DM}$ patients, in the linear regression analysis, a significant positive correlation was found between $\mathrm{HbA} 1 \mathrm{c}$ level and TyG index even after BMI, age, sex, duration of diabetes, and smoking factors were fixed. As a result of the study, it was concluded that the TyG index may be useful as a predictor of glycemic control in overweight and obese patients with type 2 DM (35). In the present study, correlation analysis of the FINDRISC diabetes risk score and TyG index showed a moderate positive correlation with age, BMI, and waist circumference. In overweight and obese individuals, the risk of developing diabetes and IR as calculated by the TyG index is higher than among indi- 
viduals of normal weight. Diabetes can be prevented by lifestyle changes, adequate physical activity, and regulation of eating habits.

Limitations: The results of this study should be interpreted within the framework of its limitations. The present study does not explain the causality of the results, as it was planned to retrospectively scan patients' files. Our results cannot be generalized because the study was conducted with a limited number of participants in a particular community. Most importantly, we could not evaluate HOMA-IR, one of the gold-standard methods for IR measurement. Insulin level measurement is not a routine test in periodic health examinations. However, the utility of the TyG index in routine clinical practice has been proven in previous studies. It is recommended that future studies include cohort-type studies covering a long follow-up period and be conducted with larger numbers of participants.

\section{CONCLUSION}

According to the results of FINDRISC, $17.1 \%$ of the participants had a high risk of developing DM in 10 years. When correlations with the diabetes risk score were examined, there were significant positive correlations with age, waist circumference, and FBS and a strong positive correlation with BMI. For the TyG index, there was a moderately significant correlation with age, BMI, waist circumference, and FBS. After linear regression analysis, $32.0 \%$ of the increase in diabetes risk score and $9.3 \%$ of the increase in TyG index were attributed to increase in BMI.

To assess the risk of developing diabetes in healthy individuals, the FINDRISC questionnaire and the TyG index, which is a predictor of IR, are easy and simple to apply. Early detection of obesity as one of the most important risk factors for diabetes development, lifestyle changes, and regulation of nutrition are among the most important tasks of family physicians. It is recommended that primary care workers be supported with in-service training on risk identification and risk management issues.

Ethics Committee Approval: Before starting the study, approval of the Necmettin Erbakan University Meram Medical Faculty's Non-Interventional Clinical
Research Ethics Committee (2019/2172) was obtained.

Conflict of Interest: All the authors declare that they have no conflicts of interest to disclose.

Funding: No funding used for the study.

Informed Consent: Consent was not obtained from the patients since it was a retrospective study.

\section{REFERENCES}

1. International Diabetes Federation. IDF Diabetes Atlas. 8th ed. 2017. Available from: https://www.idf.org/diabetesatlas (Date of access: 14.11.2019)

2. Turkey Endocrine and Metabolic Society (TEMS). Diagnosis, Treatment and Follow-up Guide of Diabetes Mellitus and Complications 2019. Available from: http://www.turkendokrin.org/files/15055_DIYABET_web(1).pdf. (Date of access: 14.11.2019)

3. Satman I, Ömer B, Tutuncu Y, et al. Twelve-year trends in the prevalence and risk factors of diabetes and pre- diabetes in Turkish adults. Eur J Epidemiol. 2013;28(2):169-80. https://doi.org/10.1007/s10654-013-9771-5

4. American Diabetes Association. Prevention or delay of type 2 diabetes. Sec. 5. In: Standards of Medical Care in Diabetes. 2015. Diabetes Care. 2015;38:31-2. https://doi.org/10.2337/dc15-S008

5. Abbasi A, Peelen LM, Corpeleijn E, et al. Prediction modelsfor risk of developing type 2 diabetes: systematic literaturesearch and independent external validation study. BMJ. 2012;18(345):e5900 https://doi.org/10.1136/bmj.e5900

6. Buijsse B, Simmons RK, Griffin SJ, Schulze MB. Risk assessment tools for identifying individuals at risk ofdeveloping type 2 diabetes. Epidemiol Rev. 2011;33:46-62. https://doi.org/10.1093/epirev/mxq019

7. Noble D, Mathur R, Dent T, Meads C, Greenhalgh T. Risk models and scores for type 2 diabetes: systematic review. BMJ. 2011;28;343:d7163. https://doi.org/10.1136/bmj.d7163

8. Liu S, Tinker L, Song Y. et al. A prospective study ofinflammatory cytokines and diabetes mellitus in amultiethnic cohort of postmenopausal women. Arch Intern Med. 2007;167(15):1676-85. https://doi.org/10.1001/archinte.167.15.1676

9. DeFronzo RA, Tobin JD, Andres R. Glucose clamp technique: a method for quantifying insulin secretion and resistance. Am J Physiol. 1979;237(3):E214-23. https://doi.org/10.1152/ajpendo.1979.237.3.E214

10. Matthews DR, Hosker JP, Rudenski AS, et al. Homeostasis model assessment: insulin resistance and beta-cell function from fasting plasma glucose and insulin concentrations in man. Diabetologia. 1985;28(7):412-9. https://doi.org/10.1007/BF00280883

11. Rhee SY, Woo JT. The prediabetic period: review of clinical aspects. Diabetes Metab J. 2011;35(2):107-16. https://doi.org/10.4093/dmj.2011.35.2.107

12. Janghorbani $M$, Amini M. Normal fasting plasma glucose and risk of prediabetes and type 2 diabetes: the Isfahan Diabetes Prevention Study. Rev Diabet Stud. 2011;8(4):490-8 https://doi.org/10.1900/RDS.2011.8.490

13. Simental-Mendía LE, Rodríguez-Morán $\mathrm{M}$, Guerrero-Romero F. The product of fasting glucose and triglycerides as surrogate for identifying insulin resistance in apparently healthy subjects. Metab Syndr Relat Disord. 2008;6(4):299-304. https://doi.org/10.1089/met.2008.0034

14. Unger G, Benozzi SF, Perruzza F, Pennacchiotti GL. Triglycerides and glucose index: a useful indicator of insulin resistance. 
Endocrinol Nutr. 2014;61(10):533-40. https://doi.org/10.1016/j.endonu.2014.06.009

15. Guerrero-Romero F, Simental-Mendía LE, González-Ortiz M, et al. The product of triglycerides and glucose, a simple measure of insulin sensitivity. Comparisonwith the euglycemichyperinsulinemic clamp. J Clin Endocrinol Metab. 2010;95(7):334751.

https://doi.org/10.1210/jc.2010-0288

16. Vasques AC, Novaes FS, de Oliveira MS, et al. TyG index performs better than HOMA in a Brazilian population: a hyperglycemic clamp validated study. Diabetes Res Clin Pract. 2011;93(3):e98-e100. https://doi.org/10.1016/j.diabres.2011.05.030

17. Mohd Nor NS, Lee S, Bacha F, Tfayli H, Arslanian S. Triglyceride glucose index as a surrogate measure of insulin sensitivity in obese adolescents with normoglycemia,prediabetes, and type 2 diabetes mellitus: comparison with the hyperinsulinemic euglycemic clamp. Pediatr Diabetes. 2016;17:458e65. https://doi.org/10.1111/pedi.12303

18. Mehran Hosseini S. Triglyceride-glucose index simulation. JCBR. 2017;1(1):11-6. https://doi.org/10.18869/acadpub.jcbr.1.1.11

19. Finnish Diabetes Association, Programme for the Prevention of Type 2 Diabetes in Finland 2003-2010. Available from: https://www.diabetes.fi/files/1108/Programme_for_the Prevention of Type 2 Diabetes in Finland 2003-2010.pdf

20. Arpacı I, Olgun N, Eren I. Assessment of diabetes risk in hospital employees. Diyabet, Obezite ve Hipertansiyonda Hemşirelik Forumu. 2019;11(1):7-11.

21. Kulak $\mathrm{E}$, Berber $\mathrm{B}$, Temel $\mathrm{H}$, et al. Determination of type 2 diabetes risk levels in individuals applying to family medicine. Turk J of Fam Prac. 2019;23(1):20-30. Available from: http:// www.turkailehekderg.org/articles/research-article/ determination-of-type-2-diabetes-risk-levels-in-individualsapplying-to-family-medicine/

22. Kutlu R, Sayın S, Koçak A. Applicability of the Finnish Diabetes Risk (FINDRISC) as a Screening Tool for Type 2 Diabetes Mellitus. Konuralp Med J. 2016;8(3):158-66. https://doi.org/10.18521/ktd.287466

23. Igci MA, Basat O. Determine type 2 diabetes development risk in adult patients presenting to family medicine department of Gaziosmanpaşa Taksim Training and Research Hospital using diabetes risk assessment test. Namık Kemal Med J. 2019;7(2):53-60.

24. Bayındır Cevik A, Karaaslan MM, Koçan S, et al. Prevalence and screening for risk factors of type 2 diabetes in Rize, Nourtheast Turkey: findings from a population-based study. Prim Care Diabetes. 2016;10(1):10-8. https://doi.org/10.1016/j.pcd.2015.06.002

25. Zhang $M$, Wang $B$, Liu $Y$, et al. Cumulative increased risk of incident type 2 diabetes mellitus with increasing triglyceride glucose index in normal-weight people: The Rural Chinese
Cohort Study. Cardiovasc Diabetol. 2017;16(1):30. https://doi.org/10.1186/s12933-017-0514-x

26. Zheng $R$, Mao $Y$. Triglyceride and glucose (TyG) index as a predictor of incident hypertension: a 9-year longitudinal population-based study. Lipids Health Dis. 2017;16(1):7. https://doi.org/10.1186/s12944-017-0410-0

27. Sanchez-Inigo L, Navarro-Gonzalez D, Fernandez-Montero A, Pastrana-Delgado J, Alfredo Martinez J. The TyG index may predict the development of cardiovascular events. Eur J Clin Invest. 2016;46(2):189-97. https://doi.org/10.1111/eci.12583

28. Zhao S, Yu S, Chi C, et al. Association between macro- and microvascular damage and the triglyceride glucose index in community-dwelling elderly individuals: the Northern Shanghai Study. Cardiovasc Diabetol. 2019;18:95. https://doi.org/10.1186/s12933-019-0898-x

29. Xie Y, Guo R, Li Z, et al. Temporal relationship between body mass index and triglyceride-glucose index and its impact on the incident of hypertension. Nutr Metab Cardiovasc Dis. 2019;29(11):1220-29. https://doi.org/10.1016/j.numecd.2019.07.003

30. Xie H, Song J, Sun L, Xie X, Sun Y. Independent and combined effects of triglyceride-glucose index on prehypertension risk: a cross-sectional survey in China. J Hum Hypertens. 2020. doi: 10.1038/s41371-020-0321-9. [Epub ahead of print] https://doi.org/10.1038/s41371-020-0321-9

31. Wang K, He G, Zhang Y, et al. Association of triglycerideglucose index and its interaction with obesity on hypertension risk in Chinese: a population-based study. J Hum Hypertens. 2020. [Epub ahead of print] https://doi.org/10.1038/s41371-020-0326-4

32. Chamroonkiadtikun $P$, Ananchaisarp T, Wanichanon W. The triglyceride-glucose index, a predictor of type 2 diabetes development: A retrospective cohort study. Prim Care Diabetes. 2020;14(2):161-7. https://doi.org/10.1016/j.pcd.2019.08.004

33. García AG, Urbina Treviño MV, Villalpando Sánchez DC, Aguilar CA. Diagnostic accuracy of triglyceride/glucose and triglyceride/HDL index as predictors for insulin resistance in children with and without obesity. Diabetes Metab Syndr. 2019;13(4):2329-34. https://doi.org/10.1016/j.dsx.2019.05.020

34. Moon S, Park JS, Ahn Y. The cut-off values of triglycerides and glucose Index for metabolic syndrome in American and Korean adolescents. J Korean Med Sci. 2017;32(3):427-33. https://doi.org/10.3346/jkms.2017.32.3.427

35. Babic N, Valjevac A, Zaciragic A, Avdagic N, Zukic S, Hasic S. The Triglyceride/HDL ratio and triglyceride glucose index as predictors of glycemic control in patients with diabetes mellitus type 2. Med Arch. 2019;73(3):163-8.

https://doi.org/10.5455/medarh.2019.73.163-168 